\title{
BIOLOGICAL ACTIVITIES AFFORDED BY THE EXTRACT FROM RARU BARK TO INHIBIT ACTION OF ALPHA- GLUCOSIDASE ENZYMES
}

\author{
Gunawan Pasaribu ${ }^{1,2}$, Wasrin Syafii ${ }^{3}$ and Latifah K. Darusman ${ }^{4}$
}

\begin{abstract}
Raru (Shorea balanocarpoides Sym) signifies one of the tree species that grows widespread in Sumatra Island. Its bark portion is commonly used by local villagers as additional ingredient mixed to nira (sugar palm juice). This addition is intended to make the juice more durable and also to enrich its taste after the juice is previously fermented to become traditional toddy beverage or the so-call "tuak". Local villagers believe that raru bark can reduce the level of blood sugar. As the relevance, the research was conducted to confirm that the extract from raru bark could afford its biological activities to inhibit alpha-glucosidase enzyme through its characterization, quantification, and isolation of its boactive compound. The extraction was performed using two methods (i.e.reflux and maceration techniques). Result revealed that the bark extract obtained from both techniques contained polyphenol compounds: flavonoid, saponin and tannin. Further, raru-bark extract from the reflux and maceration techniques could inhibit the action of alpha glucosidase enzymes on carbohydrate substrate (i.e. p-nitrophenil- $\alpha$-D-glucopyranose), at respectively $90.67 \%$ and $97.33 \%$. Meanwhile, the inhibition activities afforded by the patented drug as a control (i.e. glucobay) equaled to $97.05 \%$. Assesment using UV-VIS spectroscopy, showed that the maximum spectrum of bioactive compound in the extract was at the wave length of $288.6 \mathrm{~nm}$. Scrutiny using FTIR spectroscopy could identify the presence of aromatic groups in the compound, containing-OH, C-H, C=C, C-O and C-H bond types. Analysis using GC-MS exhibited that the compound had molecular weight of 390 with molecular structure as $\mathrm{C}_{20} \mathrm{H}_{22} \mathrm{O}_{8}$. Ultimately, data analysis scrutiny with the aid of NMR judged the most plausible compound as bioactive was 4-Glucosyl-3, 4', 5-trihydroxystilbene.
\end{abstract}

Keywords: Shorea balanocarpoides, extract, inhibition of alpha-glucosidase enzyme, bioactive compound

\section{INTRODUCTION}

Raru (Shorea balanocarpoides Symington; Dipterocarpaceae family) is a particular tree species which prevalently and widespreadly grow in Sumatra Island. Bark portion of raru is commonly added as ingredient to the sugar-palm juice or "nira" (local name).

\footnotetext{
1 Aek Nauli Forestry Research Institute, The Ministry of Forestry, Indonesia

${ }^{2}$ Corresponding Author. E-mail : gun_pa1000@yahoo.com

${ }^{3}$ Faculty of Forestry, Bogor Agricultural University, Bogor, Indonesia

${ }^{4}$ Faculty of Nature Science and Mathematic, Bogor Agricultural University, Bogor, Indonesia
} 
Such addition is intended to impart longer durability of the juice and its corresponding traditional toddy beverages or "tuak" (the popular Batak's typical drink) that result from the fermentation of sugar-palm juice. Also, it is with the purpose of enriching the taste or flavor of "nira" and "tuak" (Santiyo, 2006). According to Hildebrand (1954), there are some tree species of which that bark portion is similar in characteristics to raru bark, among others Shorea maxwelliana King, Vatica songa V.Sl. (Dipterocarpaceae family) and Garcinia sp. (Guttifera family). Erika (2005) mentioned the tree species of Shorea faguetiana Heim that develops its bark portion categorized also as raru bark. Meanwhile, Pasaribu et.al. (2007) found out another tree species called Cotylelobium melanoxylon Pierre, that also develops raru bark, which have been widely known in the Middle Tapanuli as well as in the northern part of Sumatra. The raru bark contains typical chemical substances that comprises hemicelluloses $(29.26 \%)$, alphaceluloses (37.35\%), lignin $(22.26 \%)$ and pentosans $(17.31 \%)$. Regarding the extractives in raru bark. It can dissolve partially in cold water (3.19\%), hot water $(9.08 \%)$, alcohol-benzene $1: 2(1.76 \%)$, and $1 \% \mathrm{NaOH}(19.27 \%)$, indicating that they consist of polar and non polar compound.

Not only can raru bark improve the fermenting rate of sugar-palm juice (nira) into alcohol but also it can enrich the resulting alcohol with compatible flavor (Ikegami, 1997). The raru bark is to prevent the sugar-palm juice from frothing, and control its fermentaton rate, thereby forming of the so-call toddy and local wine (tuak) and avoiding the alcohol oxidation into acelic acid (Soerianegara and Lemmens, 1994). Raru has been recognized widely by Tapanuli's society as an additional ingredient mixed to toddy beverage.

Tapanuli's society also recognize raru bark is an effective elixir for anti-diabetic drug. In this regard, local people in Sipan village, Sarudik sub-district, Middle Tapanuli regency commonly mixed a small piece of raru bark $(30 \mathrm{~cm}$ long by $5 \mathrm{~cm}$ wide) with 1 lt of water, and then allow the mixture to stand for some time. Afterwards, they drain off the water and keep only a half portion of water in the mixture. The water-drained mixture is then given to the patient suffering from diabetic disease. The progress of synthesizing the drug produced deliver from natural materials such as plants seems running parallel with the modern-drugs development through research and experiment on bio-active component. According to the villagers' experiences, raru bark can be used as efficacious diabetic remedy. Therefore, research is needed to prove such efficacy of raru bark and to analyze the bioactive content of save bark qualitatively and quantitatively. Further, obtaining knowledge regarding the bioactive content in raru is beneficial to assure those who take medicinal profession in using the drug derived from natural product, including raru.

The objective of this research was to elaborate biological activities afforded by rarubark extract on inhibiting alpha glucosidase enzyme to degrade (hydrolyze) carbohydrate substrate and to isolate the bioactive compound in the extract for its efficacy as antidiabetic remedy. 


\section{MATERIALS AND METHODS}

\section{A. Bark Material}

Bark portion was prepared and obtained from the stem of raru (Shorea balanocarpoides) tree in September 2009. The raru host trees grow abundantly in Simalungun Regency, North Sumatra Province. Meanwhile, herbarium specimens for raru species including its bark portion were already available and determined by the Bogoriense Herbarium.

\section{B. Extraction and Isolation}

The raru bark after being dried was ground to powder in size (40-60 mesh) using the milling machine. Afterwards, the raru bark powder was extracted with $70 \%$ ethanol $(\mathrm{EtOH})$ applying a maceration technique at room temperature for 4 days ( $4 \times 24 \mathrm{hrs}$ ). In another extraction method (reflax), dried raru bark was subjected to the extraction using aqueous media (water) at $100^{\circ} \mathrm{C}$ for $3 \mathrm{hrs}$. The filtrate (raru bark extracts from both maceration and reflux) were concentrated at $54^{\circ} \mathrm{C}$ using a rotary vacuum evaporator. The concentrated aqueous raru bark extracts were then freeze dried to yield a dry powder (crude extract).

Fractionation was then conducted on the crude extract using column-flash chromatography. The apparatus for this column chromatography consisted of the moving phase (solution of crude raru bark extract) and stationary phase (adsorbate). Before column chromatography run, the work started with searching for the best moving phase able to dissociate crude extract by using thin layer chromatography of which the porous layer was prepared from silica gel of $\mathrm{GF}_{254}$. After finding the best motion phase, about $5 \mathrm{ml}$ of the extract was injected to the column. Eluates flowing out of the column dissociated the crude extract at retention volume equals to $5 \mathrm{ml}$. The fractionation that proceeded after injection turned fractionated extracts into one spot which was then separated to become several fractions using preparative thin layer chromatography with silica gel as the porous layer measuring $20 \mathrm{~cm} \times 20 \mathrm{~cm}$. Finally, the identification of each of those compounds (fractions) was conducted using the spectrometry technique consecutively FTIR (Fourier-Transformed Infra Red, UV-VIS (Ultra-Violet-Visible light spectrum), GC-MS (Gas Chromatography-Mass Spectrum) and NMR (Nuclear Magnetic Resonanance).

\section{Qualitative Testing on Phytocemical}

The testing was done on crude extract of raru bark (before being fractionated) resulted from two extraction methods (maceration and reflux). The phytochemical compound as qualitatively examined in the crude extract included alkaloid, saponin, flavonoid, triterpenoid or steriod, tannin and hidroquinon (Harborne, 1987). 


\section{Testing on Inhibitory Activities of Raru Bark Extract on $\alpha$-glucosidase Enzyme}

In-vitro enzymatic was conducted on the crude extract and fractionated compound of raru bark (Sutedja, 2003). The enzyme used was $\alpha$-glucosidase existed in the yeast body (SIGMA G 3651-250UN). At first, the yeast's $\alpha$-glucosidase about $1 \mathrm{mg}$ was dissolved in phosphate buffer solution ( $\mathrm{pH}$ about 7.0), which contained bovin albumin serum. Before being used, $1 \mathrm{ml}$ of pure water-based solution containing the yeast's $\alpha$-glucosidase was taken and then diluted up to 25 times with phosphate buffer solution $(\mathrm{pH}=7.0)$. The mixture was then prepared as the reaction result consisting of $250 \mu \mathrm{l}$ of $\mathrm{p}$-nitrofenil- $\alpha$ D-glucopyranoside (SIGMA N 1377-5G) as substrate, $490 \mu$ l of phosphate buffer $(\mathrm{pH}=7.0)$ and $10 \mu \mathrm{l}$ of raru bark extract diluted in DMSO (dimethyl sulfoxide). The mixture was subsequently incubated for 5 minutes, and afterwards, $250 \mu \mathrm{l}$ of yeast's $\alpha$-glucosidase enzyme was added to it. After addition, the mixture was incubated for 15 minutes. The reaction following such addition was terminated by adding $1000 \mu \mathrm{l}$ of natrium carbonate solution. Following the termination, it turned out that $\mathrm{p}$-nitrophenol was yielded as identified through its absorbance at $400 \mathrm{~nm}$ wavelength. The sample intended for the testing $\alpha$-glucosidase enzyme dilution was dissolved in DMSO at $1 \%$ concentration. The standard blank solution was prepared through the dilution of acarbose (Glucobay) as the control. The system of reaction was described in Tables 1.

Table 1. The system of reaction

\begin{tabular}{lcccc}
\hline & Blank $(\mu \mathrm{l})$ & Control $(+)(\mu \mathrm{l})$ & Control $(-)(\mu \mathrm{l})$ & Sample $(\mu \mathrm{l})$ \\
\hline Extract & - & - & 10 & 10 \\
DMSO & 10 & 10 & - & - \\
Buffer & 490 & 490 & 490 & 490 \\
Substrate & 250 & 250 & 250 & 250 \\
& & Incubated at $37^{\circ} \mathrm{C}$ for 5 min & \\
Buffer & 250 & - & 250 & - \\
Enzym & - & 250 & - & 250 \\
& 1000 & Incubated at $37^{\circ} \mathrm{C}$ for 15 min & 1000 \\
$\mathrm{Na}_{2} \mathrm{CO}_{3}$ & & 1000 & 1000 & \\
\hline
\end{tabular}

Inhibition percentage (IB) accounting for the inhibitory activities inflicted by rarubark extract on $\alpha$-glucosidase can be calculated using the equation formula as follows:

$$
\mathrm{IP}=[(\mathrm{C}-\mathrm{S}) / \mathrm{C}] \times 100 \%
$$


Where $S$ is stands for absorbance of the investigated sample, which equals $S_{1}-S_{0}$ in that $S_{1}=$ absorbance of sample with addition of $\alpha$-glucosidase enzyme and $S_{0}=$ absorbance of sample without enzyme addition; and C is the absorbance of the blank solution (DMSO) without sample or the blank control

\section{RESULTS AND DISCUSSION}

\section{A. Moisture Content of Raru Bark}

The moisture content of raru bark, that was already identified in Bogoriense Herbarium revealed $10.36 \%$. According to Hornok (1992), the draining of water from natural drugs including those derived from raru bark can be better done at the moisture content of $10-14 \%$ because at this content, the drugs can be kept secured for a long time period without damage. The moisture content that is lower than $10-14 \%$ can endanger the raru bark extract, other it is more efficient in weight.

\section{B. Extraction and Isolation}

\section{Extraction}

Extraction method with maceration technique was selected to separate the active compounds in the raru-stem bark due to its effectiveness, being practical, secured and economical. It also aims to avoid the damage of active compounds which are vulnerable or unstable to heat. Another method of extraction which employed the reflux technique was selected to elaborate the effectiveness of boiling method for raru bark exaction as used by the villagers. The yield of raru bark extract with maceration technique (using EtOH solvent) equaled $14.97 \%$ while that with reflux was $2.13 \%$.

The difference in the yield values were brought about by the different extraction methods (i.e. maceration and reflux) which further used different solvents as well (i.e. $70 \% \mathrm{EtOH}$ and aqueos liquid or water). $\mathrm{EtOH}\left(\mathrm{C}_{2} \mathrm{H}_{5} \mathrm{OH}\right)$ which has two polarity groups (polar $\mathrm{OH}$ and non polar alkyl or $\mathrm{C}_{2} \mathrm{H}_{5}$ ) is responsible for being less polar than water $\left(\mathrm{H}_{2} \mathrm{O}\right)$ maceration technique, only compounds with polar behavior get attracted and extracted out of the raru bark, thereby soluble in $\mathrm{H}_{2} \mathrm{O}$. On the other hand, either non-polar or polar compounds in the raru bark was dissolved in $\mathrm{EtOH}$, thereby extracted out.

\section{Isolation}

The raru bark extract resulting from maceration method that performed better on inhibiting alpha glucosidase than the one from reflux method prompted to select the maceration's extract to be examined and characterized of its structure. Such selection also considered that the extract yield from maceration method was greater than that from reflux method ( $14.97 \%$ vs. $2.13 \%$, respectively). The first step in fractionation 
was to find the motion phase of eluent using thin layer chromatography (TLC) which could separate the mixed compounds into separate fractions displayed as specific spots through trial and error experiment. It turned out that the best eluent to separate mixed compounds in raru-bark extract was the mixture of methanol and chloroform in 4:11 proportion $(\mathrm{v} / \mathrm{v})$. After finding the best, the second stage of separation (fractionation) was conducted using column flash chromatography. The elution process using the latter chromatography was terminated when the last fraction revealed the same colors as that of the first fraction. There are about 313 vials containing the fractions that resulted from the fractionation. Those 313 vials were grouped into 16 fractions based on their retention factor (Rf) as described in Table 2.

Table 2. Fractions resulting from separation of compounds in raru-bark extract ${ }^{1)}$ using column-flash chromatoraphy

\begin{tabular}{ccccl}
\hline Fractions & $\begin{array}{c}\text { Tube (vial) } \\
\text { number in } \\
\text { sequence }\end{array}$ & $\begin{array}{c}\text { Overall Weight } \\
(\mathrm{g})\end{array}$ & \multicolumn{2}{l}{ Number of spot } \\
\hline 1 & $1-11$ & 0.0302 & 1 & 0.88 \\
2 & $12-15$ & 0.1067 & 1 & 0.88 \\
3 & $16-24$ & 0.1484 & 2 & $0.67 ; 0.88$ \\
4 & $25-39$ & 0.4827 & 3 & $0.34 ; 0.56 ; 0.65$ \\
5 & $40-47$ & 0.1902 & 6 & $0.34 ; 0.56 ; 0.65$ \\
6 & $48-55$ & 0.2700 & 6 & $0.27 ; 0.36 ; 0.45 ; 0.53 ; 0.65 ; 0.71$ \\
7 & $56-89$ & 0.9132 & 5 & $0.05 ; 0.27 ; 0.42 ; 0.59 ; 0.76 ; 0.91$ \\
8 & $90-114$ & 0.6351 & 4 & $0.07 ; 0.21 ; 0.40 ; 0.60 ; 0.89$ \\
9 & $115-120$ & 0.1191 & 4 & $0.13 ; 0.29 ; 0.36 ; 0.54$ \\
10 & $121-149$ & 0.3383 & 4 & $0.15 ; 0.27 ; 0.38 ; 0.52$ \\
11 & $150-160$ & 0.0922 & 4 & $0.19 ; 0.44 ; 0.60 ; 0.88$ \\
12 & $161-179$ & 0.1697 & 3 & $0.12 ; 0.25 ; 0.32$ \\
13 & $180-220$ & 0.2603 & 1 & 0.08 \\
14 & $221-247$ & 0.3006 & 2 & $0.07 ; 0.24$ \\
15 & $248-260$ & 0.0553 & 2 & $0.09 ; 0.88$ \\
16 & $216-313$ & 0.1604 & 2 & $0.09 ; 0.88$ \\
\hline
\end{tabular}

Notes: ${ }^{1)}$ Extracted using maceration method with $70 \% \mathrm{EtOH}$ solvent; $\mathrm{Rf}=$ retention factor $=$ the distance traveled by a spot of particular separated compounds over the distance traveled by the solvent front (both distances achieved at the same time) 
Those 16 fractions were further examined together based on similar $\mathrm{Rf}$ values which were close together; and then could be grouped into 5 main fractions. The main fractions 1, 2, 3, 4 and 5 were each monitored and examined with the TLC analysis (Table 3).

Table 3. Main Fraction from separation of compounds

\begin{tabular}{ccl}
\hline Main Fraction No & Number of spot & \multicolumn{1}{c}{ Rf } \\
\hline 1 & 2 & $0.67 ; 0.87$ \\
2 & 4 & $0.44 ; 0.54 ; 0.67 ; 0.87$ \\
3 & 5 & $0.27,0.33,0.47,0.64 ; 0.87$ \\
4 & 6 & $0.08,0.28,0.40 ; 0.53,0.62 ; 0.86$ \\
5 & 4 & $0.08,0.28,0.40 ; 0.52$ \\
\hline
\end{tabular}

3. Characterization of chemical compounds

a. Characterization with analytic TLC and two dimensional TLC

The characterization was conducted on the spot (fraction) that resulted from PTLC with Rf 0.54 using both analytical or two-dimensional TLC. Analytical TLC used the solvent of methanol-chloroform (in 4:11 mix proportion), while for two-dimensional TLC it employed methanol-chloroform (5:12) as the second solvent. Both analytical and two dimensional TLC came out with one spot, indicating that the compound in the spot was pure enough.

\section{b. Characterization with UV-VIS Spectroscopy}

The characterization of such pure compound by UV-VIS spectrophotometer was conducted using ethanol (EtOH) solvent. Result showed that there occurred maximum absorption at $288.6 \mathrm{~nm}$ wavelength (Figure 1), signifying that the compound contained conjugated phenolic chromophores.

c. Characterization using FTIR Spectrophotometry

Result of FTIR spectometry's identification and characterization on the pure compound brought out several absorption bands stretching at wavenumbers $3366 \mathrm{~cm}^{-1}$, $2931 \mathrm{~cm}^{-1}, 1451-1612 \mathrm{~cm}^{-1}, 1385 \mathrm{~cm}^{-1}, 1196 \mathrm{~cm}^{-1}$, and $655-694 \mathrm{~cm}^{-1}$, indicating the presence of particular bond types (Table 4 and Figure 2). 
Report Date: 15:58:10, 07/03/2009

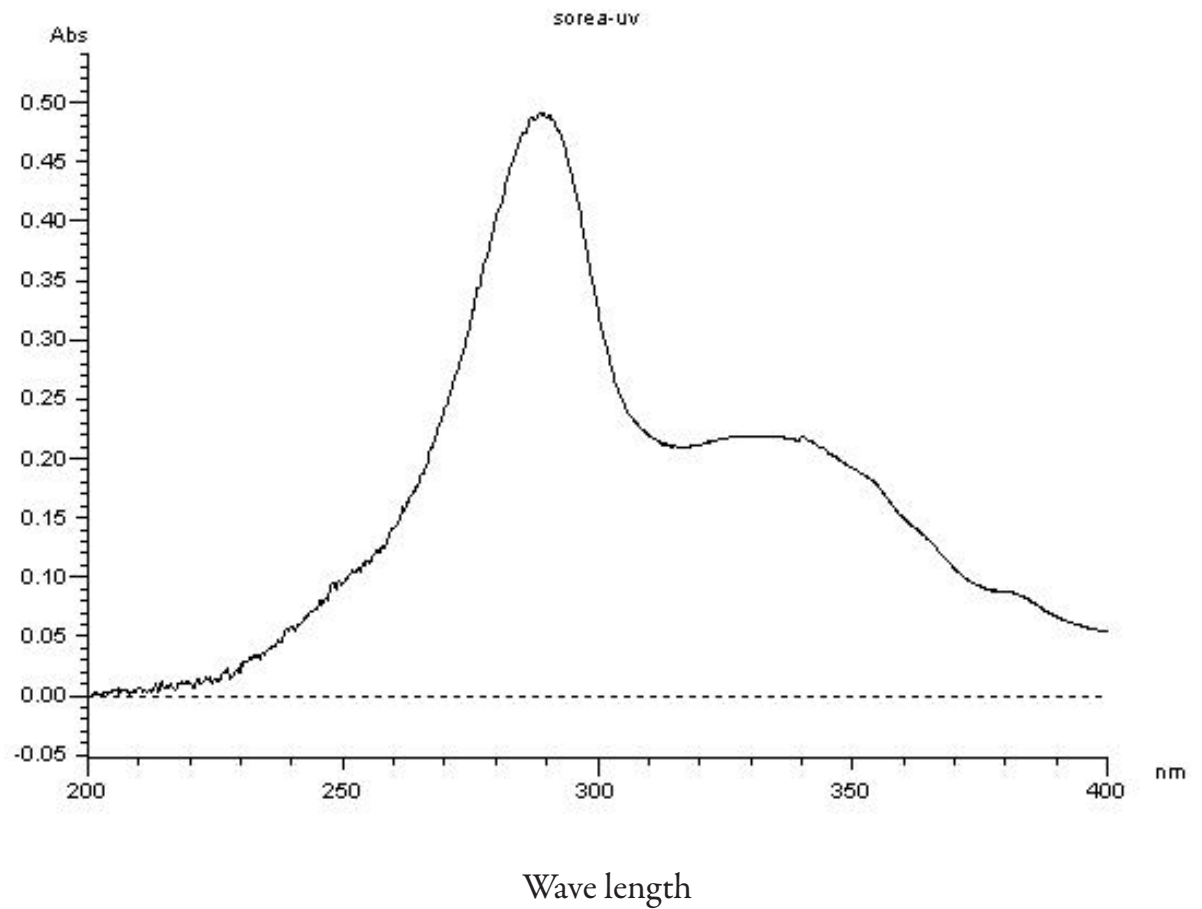

Figure 1. Absorption spectrum of singel (pure) compound derived from raru-bark extract using UV-Vis spectroscopy

Table 4. Characterization of infra red absorption bands of the pure compounds derived from raru-bark extract, and prediction (indication) of each of the corresponding bond types

\begin{tabular}{cccc}
\hline No. & Wavenumber $\left(\mathrm{cm}^{-1}\right)$ & Stretching $\left(\mathrm{cm}^{-1}\right)$ & $\begin{array}{c}\text { Prediction or indication of } \\
\text { bond types }\end{array}$ \\
\hline 1 & 3366 & $3200-3600$ & - OH (alcohol, phenol) \\
2 & 2931 & $2850-2960$ & C-H (alifatic) \\
3 & $1451-1612$ & $1450-1600$ & C=C (aromatic) \\
4 & 1385 & $1350-1470$ & C-H (alkana) \\
5 & 1196 & $1080-1300$ & C-O (alcohol) \\
6 & $655-694$ & $675-870$ & C-H (aromatic) \\
\hline
\end{tabular}

Source : Fessenden \& Fessenden (1986) 


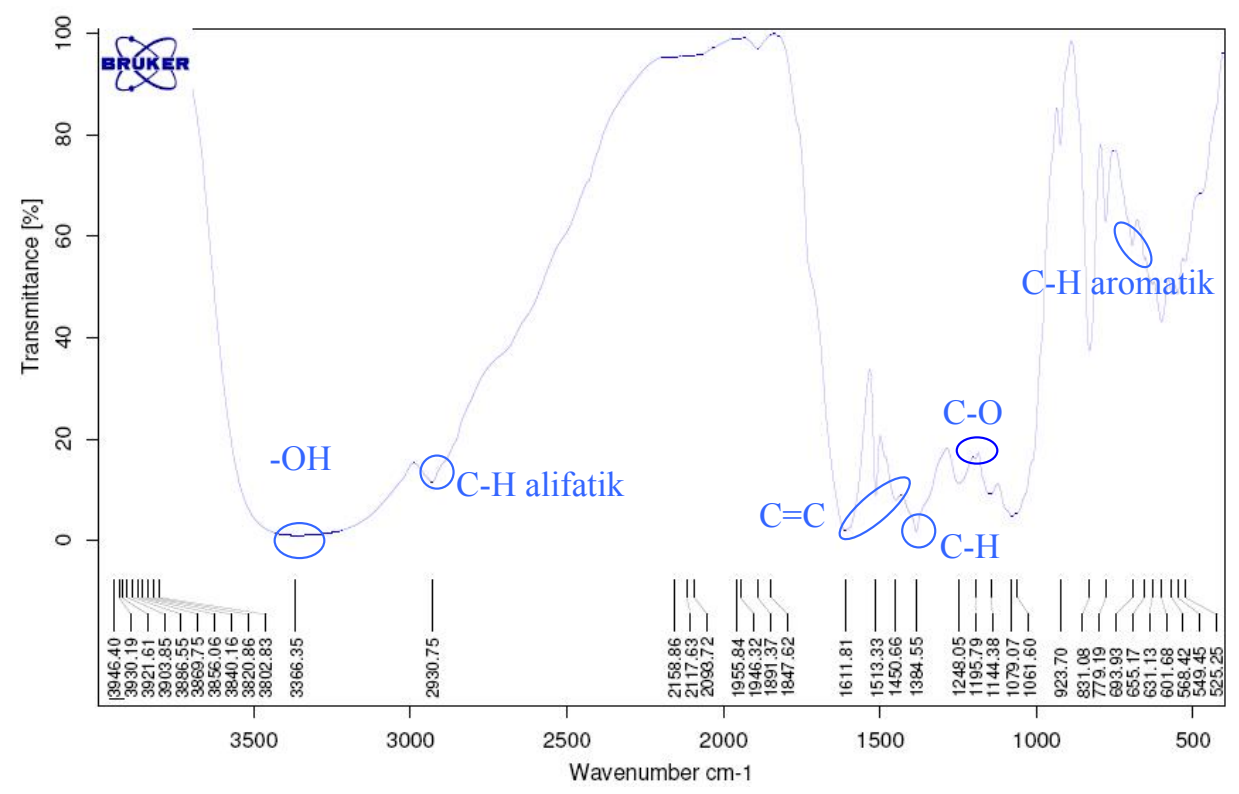

Figure 2. FTIR (fourier-transformed infra red) absorption spectra of the pure compound derived from raru-bark extract

Interpreting the spectra based on the reference (Fessenden and Fessenden, 1986), the compound was indicated or predicted to have bond types or functional group of $\mathrm{O}-\mathrm{H}, \mathrm{C}-\mathrm{H}, \mathrm{C}=\mathrm{C}, \mathrm{C}-\mathrm{O}$ and $\mathrm{C}-\mathrm{H}$ aromatic. Further, the absorption spectrum at absorption $3366 \mathrm{~cm}^{-1}$ proved the compound to have $\mathrm{OH}$ group which were able to hydrogen-bond between molecules. The absorption spectra at $2931 \mathrm{~cm}^{-1}$ confirmed the existence of $\mathrm{C}-\mathrm{H}$ aliphatic bond type, while the spectrum at $1585 \mathrm{~cm}^{-1}$ confirmed the existence of C-H bond type. There was also absorption spectrum at $1451-1612 \mathrm{~cm}^{-1}$ indicating the presence of $\mathrm{C}=\mathrm{C}$ bond type, while the spectrum at $1196 \mathrm{~cm}^{-1}$ indicated $\mathrm{C}-\mathrm{O}$ bond type. The spectrum at $655-696 \mathrm{~cm}^{-1}$ was attributable to the $\mathrm{C}-\mathrm{H}$ bending.

\section{d. Characterization using GC-MS and NMR spectrometry}

In addition to employing UV-Vis and FTIR spectrometry, characterization and identification of the compound was also conducted using other spectrometry methods, which incorporated GC-MS and NMR. The GC-MS was used to determine the molecular weight of the unknown (investigated) compound. Results of GC-MS spectroscopy revealed that there were two similar peaks, i.e. at mass ions of 15.76 and 15.89 (Figure 3). This indicated that compound was not pure enough. Further characterization at mass ion of 15.76 brought out two molecular weights at 183 and 390. Meanwhile another characterization at mass ion 15.89 gave rise two molecular weight as 
well at 183 and 390. All those results indicated that the compound consisted of mixture of compounds with different molecular weights. Further, referring to the Dictionary of Natural Products Database (Buckingham, 2007), the compound with molecular weight at 390 was indicated to have structure similar to the one determined by guide of early spectroscopy, which contained aromatic and glycosidic group.

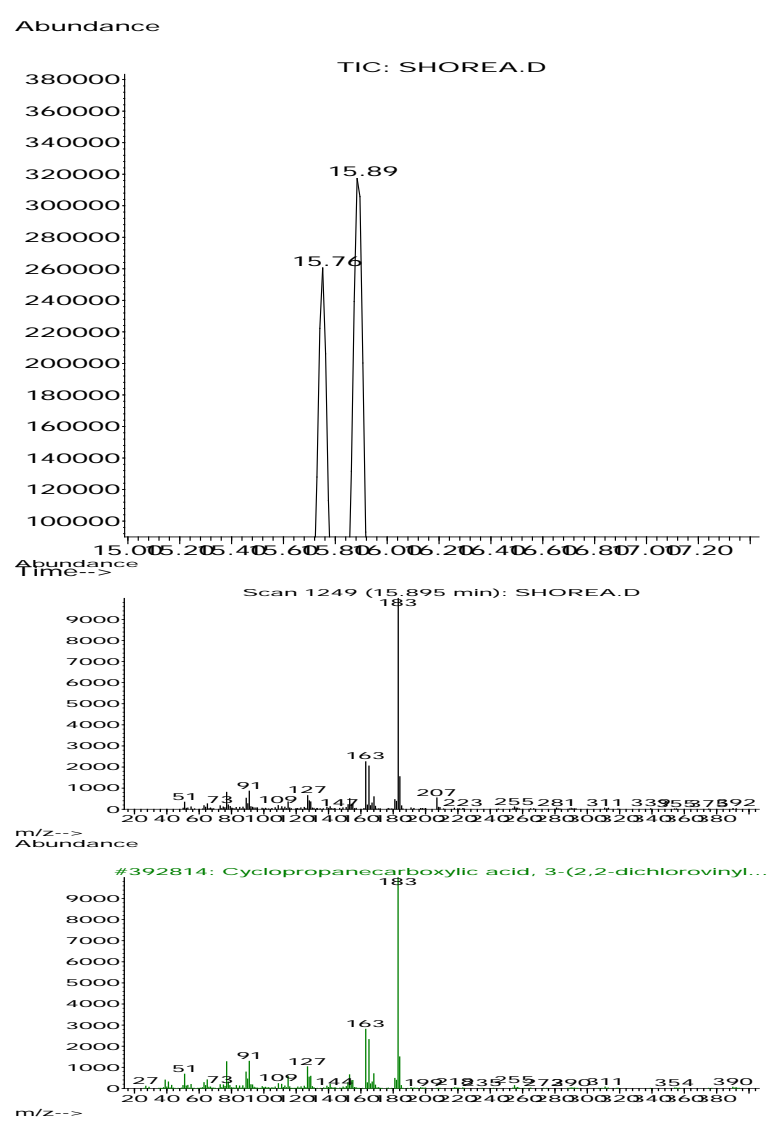

Figure 3. GC-MS spectra of investigated compound

The NMR spectrometry included those of the proton magnetic resonance ( $\left.{ }^{1} \mathrm{H}-\mathrm{NMR}\right)$, and carbon- 13 magnetic resonance $\left({ }^{13} \mathrm{C}-\mathrm{NMR}\right)$. The chemical shift value was observed and scrutinized at ${ }^{1} \mathrm{H}-\mathrm{NMR}$ and ${ }^{13} \mathrm{C}-\mathrm{NMR}$ as indication of electro negativity of deshielded elements for consecutively proton $(\mathrm{H})$ and isotope carbon $\left({ }^{13} \mathrm{C}\right)$ under different molecular environments. The chemical shift was approximated relative to that of standard element (tetramethylsilane or abbreviated TMS) in accordance with the standard procedure (Chem Draw Ultra 10 Software). 
Results of ${ }^{1} \mathrm{H}-\mathrm{NMR}$ spectroscopy revealed shows the chemical shift $(\delta \mathrm{H}, \mathrm{ppm})$ at 3.31 (doublet), 3.79 (quartet), 5.03 (doublet), 6.22 (doublet), 6.4 (doublet), 6.51 (doublet), 6.74 (doublet), 6.94 (doublet), 6.72 (doublet), 7.50 (doublet). Further, the ${ }^{13} \mathrm{C}-\mathrm{NMR}$ spectroscopy brought out the chemical shift $(\delta \mathrm{C}, \mathrm{ppm})$ at the range of 48.92-216.71; the shift at 156.40-159.19 ppm, 71.81-78.09 ppm, and $48.98 \mathrm{ppm}$ indicated the presence of consecutively aromatic, $\mathrm{C}-\mathrm{O}$, and methyl $\left(\mathrm{CH}_{3}\right)$ groups on the investigated compound derived from raru-bark extract.

The overall serenity result of both ${ }^{1} \mathrm{H}-\mathrm{NMR}$ and ${ }^{13} \mathrm{C}-\mathrm{NMR}$ turned out that the most plausible chemical formula for the compound was indicatively 4-glucosyl3,4',5-trihydroxystilbene synonym with 2-D-Glucopyranosyl-5-[2-(4-hydroxyphenyl) ethenyl]-1,3-benzenediol and synonym with 4-C--D-Glucopyrano sylresveratrol and also synonim with resveratrol 4-C-glucoside compound with molecule weigh 390.389. Correspondingly, it chemical formula was $\mathrm{C}_{20} \mathrm{H}_{22} \mathrm{O}_{8}$. The predicted molecular structure of the compound is shown in Figure 4.

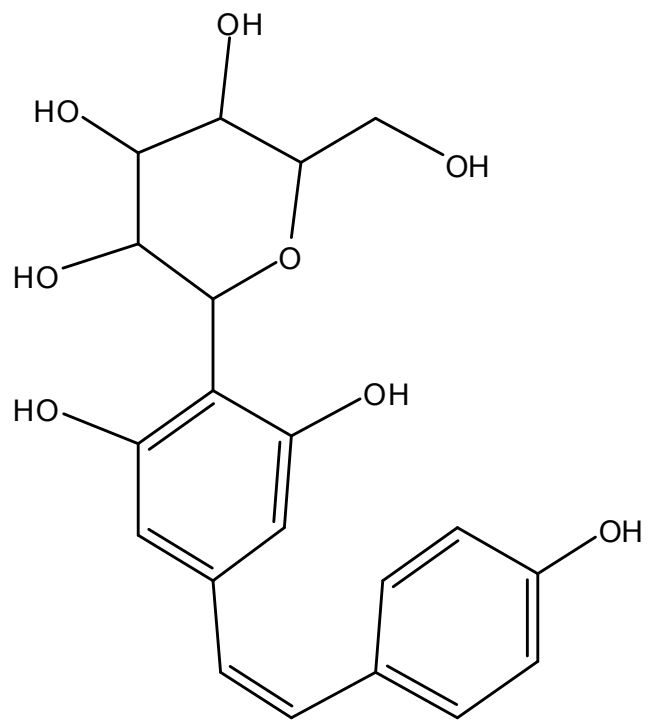

Figure 4. The compuound derived from raru-bark extract, strongly predicted or assumed as 4-glucosyl-3,4',5-trihydroxystilbene

In relevant, Nanik (2008) reported that Shorea pinanga represented one of the species that belonged to Shorea genera, and further verified that its wood portion contained four compound of oligoresveratrol, i.e. (-)-a-viniferin, laevifonol, (-)-ampelopsin A, and (-)-hopeafenol. In this species, there were two compounds, i.e (-) -a-viniferin and (-)-hopeafenol that showed weak activity against prawn fry by Artemisia salina and cell 
of murine P-388 leukemia. Meanwhile, the bark portion of it corresponding stem have never been reported to contain oligoresveratrol compound.

Saroyobudiono et.al. (2008) reported the presence of new derivatives of oligostilbenoid in Shorea gibbosa plant, comprising the compounds of diptoindonesin F (1), (-)-ampelopsin A (2), a - viniferin (3), ampelopsin E (4), (-)-vaticanol B (5), and (-)-hemsleyanol D (6). Those derivative compounds were extracted from its corresponding bark portion using methanol solvent. Further, the chemical structure of those compounds was determined and interpreted based on the data analysis from the spectroscopy techniques including UV, IR, NMR 1-D and 2-D, and MS. It turned out that those oligostilbenoid derivates afforded their cytotoxic activities as have been tested against the cells of murine leukemia P-388, whereby ampelopsin A (designated as compound 2) and ampelopsin (designated as compound 4) revealed the best efficacy.

In another development, the efficacy of stilbene as antidiabetic drug has been conducted by Chen et.al (2009). In this regard, some stilben compound were isolated from the rhizome of rhubarb, which included among other rhaponticin (3,5-dihydroxy4'-methoxystilbene 3-O-beta-D-glucopyranoside). Those compounds exhibited efficacious hypoglycemic effect on mouse and rat which had been previously inducted with streptozotocin diabetes type-1. These results proved that giving rhaponticin oral (at $125 \mathrm{mg} / \mathrm{kg}$ ) brought about significant reduction in the level of blood glucose and improved the glucose tolerance against oral at $\mathrm{KK} /$ ay rat diabetes. Still related, Heo et.al (2007) conducted investigation on antidiabetic effectiveness of 2,5-dihydroxy-4,3di(beta-D-glucopyranosyloxy)-trans-stilbene (DGTS) which was isolated from Morus bombycis Koidzumi plants. Such effectiveness was judged from the testing of DGTS on a mouse which had been previously inducted with streptozotocin. In this regard, the use of DGTS at $200-800 \mathrm{mg} / \mathrm{kg}$ dosage was effective to improve the mouse hyperglycemic. Through observation and scrutiny involving histology aspect indicated that DGTS could prevent the atrophy at pancreas beta cell and change degenerative tissue, which occurred in Langerhans Island. This research result suggested DGTS was advantageous as remedial treatment for diabetes type 1 .

\section{Qualitative Testing on Phytochemical Compounds}

Result of qualitative testing on phytochemical compound in the crude extract removed from raru bark revealed that the extract using either maceration or reflux extraction method contained compounds: flavonoid, tannin and saponin (Table 5).

It was reported that flavonoid and saponin compounds could act as antihyperglycemia (Studiawan and Mulya, 2005). In this regard, they performed experiment with Salam (Polyantha eugenia) leaves and revealed the leaves contained flavonoid and tannin, which can reduce the blood- sugar level in the rat as inducted with aloxan. Later on, Raju and Balaraman (2008) reported that giving saponin compound to wistar rats resulted in significant decrease of the sugar level. 
Table 5. Results of qualitative testing on phytochemical compound in crude raru-bark extract

\begin{tabular}{|c|c|c|c|}
\hline \multirow{2}{*}{ No } & \multirow{2}{*}{ Compound } & \multicolumn{2}{|c|}{ Extraction Methods } \\
\hline & & Maceration & Reflux \\
\hline 1 & Flavonoid & +++ & ++ \\
\hline 2 & Tannin & +++ & ++ \\
\hline 3 & Saponin & +++ & ++ \\
\hline 4 & Titerpenoid & - & - \\
\hline 5 & Steroid & - & - \\
\hline \multirow[t]{5}{*}{6} & Hydrokuinon & - & - \\
\hline & Alkaloid: & & \\
\hline & - Dragendorf & - & - \\
\hline & - Wagner & - & - \\
\hline & - Meyer & - & - \\
\hline
\end{tabular}

Notes: $(-)=$ negatif or not detected; $(++)=$ positively detected $;(+++)=$ highly or very positively detected

\section{Inhibitory Activity by Raru Bark on Alpha-Glucosidase Enzyme}

1. Inhibitory activity by raru bark crude extract on alpha-glucosidase enzyme

Such inhibitory activities by raru bark extract was tested to examine and characterize its role on inhibiting alpha $(\alpha)$-glucosidase enzyme. In this regard, the $\alpha$-glucosidase enzyme would hydrolyze p-nitro-phenyl- $\alpha$-D-glucopironose in the substrate (Table 1) yielding glucose and p-nitro-phenol which was yellow in color. Consequently, the indication of $\alpha$-glucosidase enzyme action was judged and measured from the appearance of yellow-colored absorbance caused by p-nitro-phenol as hydrolysis results. In turn out that the substrate added with raru-bark extract revealed the decrease in $\alpha$-glucosidase enzyme action as indicated by the lowering intensity of yellow-colored absorbance. Therefore, strong indication aroused that raru bark extract afforded as inhibitor of such enzyme action. Further, the data regarding inhibition activities of raru bark extract as obtained from the two extraction methods are illustrated in Figure 5.

The illustration in Figure 5 was assisted by statistical analysis to explore the effect of different extraction methods. Result revealed that no-significant difference in inhibition activities occurred between raru-bark extracts yielded by the two different extraction methods. This implied that both methods brought out the extracts with similar effectiveness on inhibiting $\alpha$-glucosidase action. However, inhibition activity 


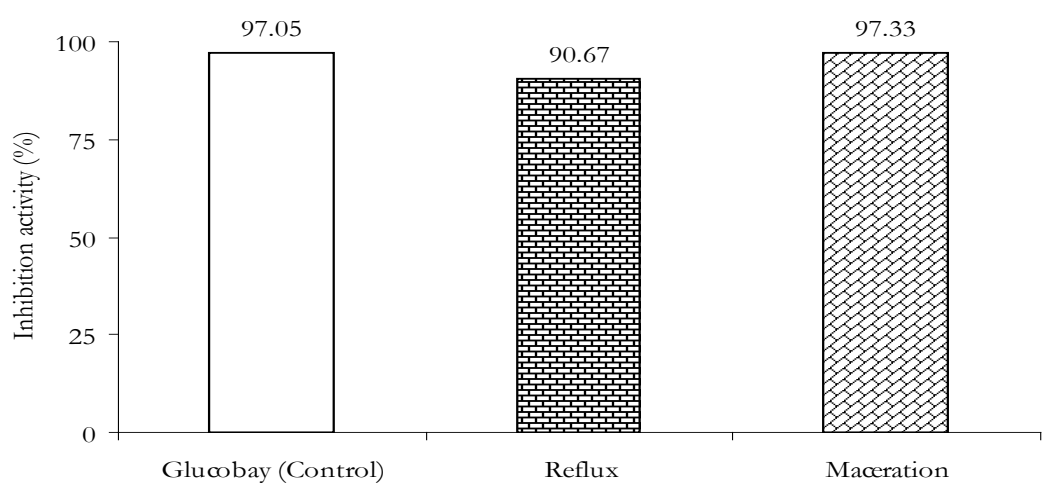

Remarks: ${ }^{1)}$ As obtained from two exraction methods (i.e. maceration and reflux tecniques)

Figure 5. Inhibition activity afforded by raru-bark extract 1 ) on $\alpha$-glucosidase-enzyme action

of the bark extract derived from maceration method (97.33\%) is better than derived from reflux method $(90.67 \%)$. Further, inhibition activities afforded the extract resulting from both methods were nearly equal (97.05\%) compared to those of the control or the patented drug (glucobay). As interesting case, in comparison with the inhibition activity on $\alpha$-glucosidase action, afforded by particular compounds derived from other natural (vegetation) products, there was a noticeable difference in such activity. As the relevance, Subramanian et.al. (2008) reported that the extract obtained from particular plant species, i.e. Andrographis pianiculata and andrographolide afforded to inhibit $\alpha$-glucosidase action. Further, the use of Andrographis pianiculata extract at $62.5 \mathrm{mg}$ $\mathrm{ml}^{-1}$ concentration resulted in maximal inhibition activity. As such, the inhibition activity varied about $3.2-89.0 \%$. Further, it turned out that the Andrographolide at $1.25-10 \mathrm{mg} \mathrm{ml}^{-1}$ could achieve 3.5-53.7\% inhibition activity on $\alpha$-glucosidase action.

2. Inhibition of alpha glucosidase by raru bark extract in fractions

Result of testing on alpha $(\alpha)$-glucosidase enzyme by raru-bark extract in fractions after chromatographic separation revealed that each fraction afforded enzyme-inhibition, which varied about $83.13-99.39 \%$ (Figure 6.) 


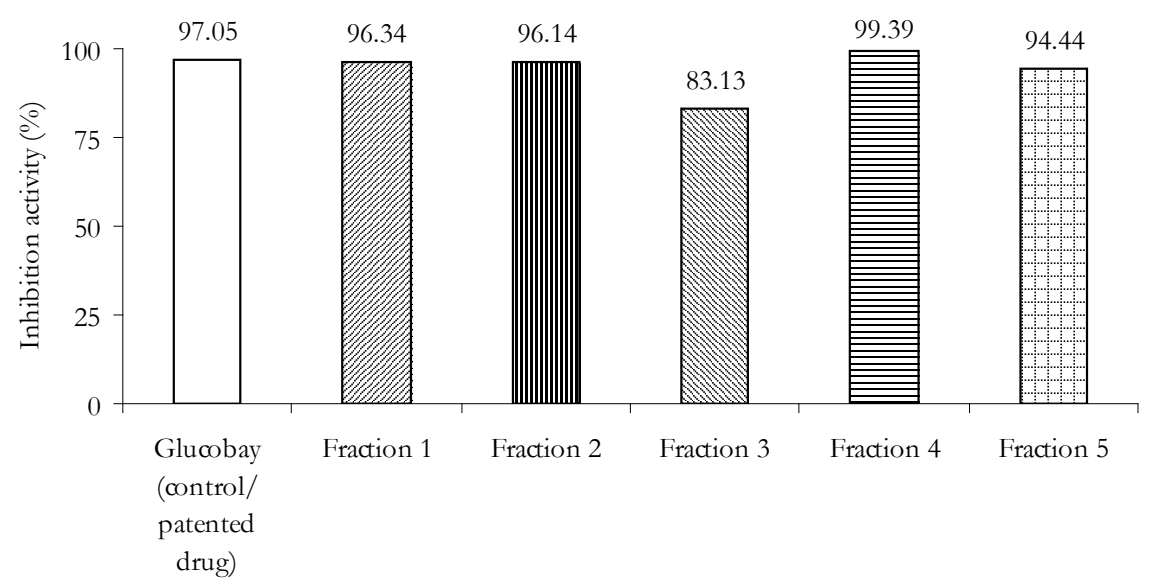

Figure 6. Inhibition of alpha-glucosidase enzyme by raru bark extract in fractions after chromatographic separation

Examination using preparative thin layer chromatography (PTLC) one spot following injection of $5 \mathrm{ml}$ of crude-extract sample into the flash-column chromatography, yielded 4 fractions with their specific weight and specific $R f$ values. Those $R f$ values were consecutively $0.40,0.54,0.67$ and 0.87 . Further, each of those 4 fractions was also tested of their inhibition against $\alpha$-glucosidase action (Table 6).

Table 6. Characteristic of the four fractions ${ }^{1)}$ as examined using preparative thin layer chromatography (PTLC)

\begin{tabular}{cccc}
\hline & \multicolumn{3}{c}{ Characteristics } \\
\cline { 2 - 4 } Fraction No & Rf & Weight $(\mathrm{mg})$ & $\begin{array}{c}\text { Inhibition action against } \\
\alpha \text {-glucosidase }(\%)\end{array}$ \\
\hline- & $\begin{array}{c}\text { Control } \\
\text { (glucobay) }\end{array}$ & - & 97.05 \\
1 & 0.40 & 8.2 & 99.68 \\
2 & 0.54 & 35.4 & 97.08 \\
3 & 0.67 & 7.7 & 89.61 \\
4 & 0.87 & 11.9 & 19.81 \\
\hline
\end{tabular}

Notes : ${ }^{1)}$ Originated from one spot that resulted from column flash chromatography 
Judging from the percent of inhibition action on $\alpha$-glucosidase, the best inhibition action was selected at $\mathrm{Rf} 0.40$ (Table 4). However, such selection could be undersized or underrated by the relatively small weight of the fraction $(8.2 \mathrm{mg})$. Therefore, the characterization of selecting the best inhibition of the fraction at 0.54 was regarded as high enough due its heavier weight $(35.4 \mathrm{mg})$.

Research on the inhibition activity afforded by the tree portion of Shorea species has been conducted by Hirano et.al. (2003). In this research, they isolated five type of tannin compounds from the heartwood portion from Shorea laeviforia trees, i.e gallic acid, dilactone flavogallonat acid, dilactone valoneic acid, gallagyldilactone, and ellagic acid; and found out that those compounds revealed inhibitory activity against 5-a-reductase enzyme in the mouse liver. As interesting case, dilactone valoneic acid and gallagyldilactone proved showing such inhibition, while gallic acid and ellagic did not. On the contrary, dilactone flavogallonat acid stimulated the activity of 5- $\alpha$-reductase, although this compound exhibited structure almost similar to dilactone valoneic acid. Further, kinetic assessment on dilactone valoneic acid and gallagyldilactone indicated that their inhibitory of preventing activity on 5 - $\alpha$-reductase against the substrate (carbohydrate compounds) was not competitive with that of testosterone, but partially competitive with that of the cofactor Nicotinamide adenine dinucleotide phosphate (NADPH).

\section{CONCLUSION}

The extract from raru bark, employing two extraction methods (i.e. reflux and maceration techniques), turned out to contain flavonoid, saponin and tannin. Raru bark extract from the reflux and maceration techniques could inhibit the action of alphaglucosidase enzyme on carbohydrate substrate (i.e. p-nitrophenil- $\alpha$-D-glucopyranose). With the inhibition of $90.67 \%$ and $97.33 \%$ respectively. Meanwhile, the inhibition activity exerted by the patented drug as the control (i.e. glucobay) equals $97.05 \%$. Through the assessment using UV-VIS spectroscopy, the maximum spectrum of bioactive compound in the extract was $288.6 \mathrm{~nm}$ wavelengths. Scrutiny using FTIR spectroscopy could identify the presence of aromatic groups in the compound, containing- $\mathrm{OH}, \mathrm{C}-\mathrm{H}$, $\mathrm{C}=\mathrm{C}, \mathrm{C}-\mathrm{O}$ and $\mathrm{C}-\mathrm{H}$ bond types. Analysis using GC-MS exhibited the compound had molecular weight at 390 with molecular structure as $\mathrm{C}_{20} \mathrm{H}_{22} \mathrm{O}_{8}$. Ultimately, data-analysis scrutiny with the aid of NMR judged the most plausible compound as bioactive was 4-glucosyl-3, 4', 5-trihydroxystilbene.

\section{REFERENCES}

Buckingham, J. 2007. Dictionary of Natural Products (DVD) London, United Kingdom.

Chen, J., M. Ma, Y. Lu, L. Wang, C. Wu, and H. Duan. 2009. Rhaponticin from Rhubarb rhizomes alleviates liver steatosis and improves blood glucose and lipid profiles in KK/Ay diabetic mice. Planta Med 75: 472-477. 
Erika, S.S. 2005. Uji Toksisitas ekstrak kulit batang raru (Shora faguetiana Heim) menggunakan brine shrimp lethality test (BSLT). Skripsi. Departemen Teknologi Hasil Hutan, Fakultas Kehutanan IPB. Bogor. (Unpublished report)

Fessenden, R.J dan J.S. Fessenden,1986. Kimia Organik Jilid 1. Penerjemah Aloysius Hadyana Pudjaatmaka. Erlangga Jakarta.

Harborne, J.B., 1987. Metode Fitokimia: Penuntun Cara Modern Menganalisa Tumbuhan. Edisi ke-2. Penerjemah Padmawinata K. Bandung: ITB.

Heo, S.I., Y.S. Jin, M.J. Jung, and M.H. Wang, 2007. Antidiabetic properties of 2,5-Dihydroxy-4,3'-Di(beta-D-Glucopyranosyloxy)-trans-Stilbene from mulberry (Morus bombycis Koidzumi) root in streptozotocin-induced diabetic Rats. Journal of Medicinal Food 10: 602-607.

Hildebrand, F.H., 1954. Daftar Nama Pohon-Pohonan 'Tapanuli' Sumatera Utara. Laporan Balai Penyelidikan Kehutanan No.67. Balai Penyelidikn Kehutanan Bogor. Indonesia. (Unpublished report)

Hirano, Y., R. Kondo, and K. Sakai, 2003. 5 $\alpha$-Reductase inhibitory tannin-related compounds isolated from Shorea laeviforia. Journal of Wood Science 49: 339-343.

Hornok, L. 1992. Cultivation and Processing of Medical Plant. A Wiley Medical Publication. Baffins Lane, Chichester, 350p.

Ikegami, S. 1997. Tuak dalam Masyarakat Batak Toba. Laporan Singkat tentang Aspek Sosial-Budaya Penggunaan Nira. Annual Report of the University of Shizuoka. Part 5. Hamamatsu College No.11-3. (Unpublished report)

Nanik, S.A. 2008. Isolasi, Penentuan Struktur, dan Skrining Antikanker Senyawa Oligoresveratrol dari Shorea pinanga (Dipterocarpaceae). Fakultas Matematika dan Ilmu Pengetahuan Alam Universitas Airlangga. (Unpublished report)

Pasaribu, G. B. Sipayung, dan G. Pari, 2007. Analisis komponen kimia empat jenis kayu asal Sumatera Utara. Jurnal Penelitian Hasil Hutan 25: 327-333.

Raju, K and R. Balaraman, 2008. Research article antidiabetic mechanisms of saponin of Momordica cymbalaria. Pharmacognisi Magazine 4:197-206.

Santiyo. 2006. Beberapa Jenis Pohon Sebagai Sumber Penghasil Bahan Pengawet Nabati Nira Aren (Arenga pinnata Merr). Info Hasil Hutan 12: 67-74.

Saroyobudiono, H., D.J. Lia, M.S. Yana, A.A. Sjamsul, H.H. Euis, L. Jalifah and M.S. Ikram, 2008. Oligostilbenoids from Shorea gibbosa and their cytotoxic properties against P-388 cells Journal of Natural Medicines. 62: 95-98

Soerianegara, I. and R.H.M.J. Lemmens, 1994. PROSEA. Plant Resources of South East Asia 5 (1) Timber Trees : Major Commercial Timbers. Bogor. 
Subramanian, R., M.Z. Asmawi and Amirun Sadikun. 2008. In vitro $\alpha$-glukosidase and $\alpha$-amylase enzyme inhibitory effect of Andrographis paniculata extract and andrographolide. Acta Biochimica Polinica 55: 391-398. (Unpublished report)

Sutedja, L. 2003. Bioprospecting tumbuhan obat indonesia sebagai sediaan fitofarmaka antidiabetes. Laporan Kemajuan Tahap II Riset Unggulan Terpadu, Pusat Penelitian Kimia-LIPI.

Studiawan, H. dan M.H. Santosa, 2005. Uji aktivitas kadar glukosa darah ekstrak daun eugenia poliantha pada mencit yang diinduksi dengan aloksan. Media Kedokteran Hewan 21: 62-65. 